\title{
The Rhizomatic-Moving with the Difference Aid: A Study on Childhood in Elementary School Grades Teaching of Nine Years
}

\author{
Larissa Monique de Souza Almeida Ribeiro, ${ }^{1, *}$, Luiz Artur dos Santos Cestari ${ }^{2}$ \\ ${ }^{1}$ Departamento de Educação, Universidade do Estado da Bahia, Guanambi-BA, Brazil \\ ${ }^{2}$ Philosophy and Human Sciences Department, University of Southwestern Bahia, Vitória da Conquista-BA, Brazil \\ *Corresponding author: larymonik2@hotmail.com, lacestari@hotmail.com
}

\begin{abstract}
This article is a call to reflect on some of the changes made to schools through the policy of extending elementary grade school to a nine-year period, which includes the six year old child and reorganizes the period and the school spaces through a suggested proposal for the curriculum and put the discussion of childhood in school on the agenda. Its main objective is to follow up the child in the curricular movements of the Centro Educational Senador João Calmon, a school in the initial years of elementary grades education located in the Jequié County, State of Bahia, after the implantation process and implementation of the Nine-Years Elementary School Teaching. The methodological contribution is inspired on cartographic research, on the possibility of processes accompanying of subjectiveness, in an attempt to aim the singular processes that make up the subject. In this sense, movements were carried out with the help of research devices, field diaries, conversations and story-making up workshops. In order to do so, it is argued that children's ways of life are made up by the curriculum, being necessary the discussion about the ordinations and routines, but also about the multiplicities of the rhizomes and the movements with the rhizomatic curriculum, curriculum that is not located on the prescribed document, but which is constructed as a difference.
\end{abstract}

Keywords: curriculum, difference, nine-years elementary grade school, childhood

Cite This Article: Larissa Monique de Souza Almeida Ribeiro, and Luiz Artur dos Santos Cestari, "The RhizomaticMoving with the Difference Aid: A Study on Childhood in Elementary School Grades Teaching of Nine Years." American Journal of Educational Research, vol. 5, no. 7 (2017): 782-787. doi: 10.12691/education-5-7-14.

\section{Introduction}

We emphasize that the Nine-Years Elementary School Teaching is a public policy that justifies the entry of six-year-olds in this school modality, with the perspective of ensuring that he or she has a longer time of school life and with more opportunities to learn. Therefore, the option for the age group of 6 to 14 years for the Nine-Years Elementary School changes the organization of school space and the lifetime of the child. These modifications are prominent in school and the school logic needed to be rethought.

The alteration changes the whole school conception, because the administrative staff, teachers, management team, parents, students, should know, discuss and understand how changes would happen in the school practice. The federal agency left it under the responsibility of each educational system to standardize its implementation, and each school unit could independently draw up its expansion plan according to its peculiarities. In order to guide schools, the Department of Education of Jequié county created the Curriculum Guidelines for Elementary Grade School in the County of Jequié. [1] The document is the main articulator between the County Education
Department and schools for the construction of the political-pedagogical project articulated to the new Elementary School.

The inclusion of the six-year-old child in the elementary education, according to the Guidelines of the Education Department, [1] makes it clear for the need to elaborate a specific pedagogical proposal and, thus, to give new meaning to the concept of childhood to Elementary School: This initiative requires from the County of Jequié Teaching "guiding guidelines for the integral care of the child in its physical, psychological, intellectual and social aspect, as well as goals for the expansion of care with quality assurance." [1]

Who is this six-year-old child? What will the first year or level class be like? How does one organize the space and time in school with this new proposal? The concerns which went from the organization of the school structure to the pedagogical changes, produced a complexity in the implementation of the policy in the school.

It is worth highlight that the view of childhood has been associated with immaturity and minority for years. The absence of a specific brand, the inferiority before the adult man and the non-importance are some of the marks that stood out. Corazza [2] believes that historical silence in the history of childhood reveals the absence of questioning, not because children did not exist, but from Ancient Times 
to the Modern Age, there was no childhood, neither the social and cultural figure "child."

The idea of education as a forger of character in the first stage of human life perpetuated. Being a child meant not to have a form, being malleable, with whom anything could be done. [3] Thus, over the centuries, schooling has been playing a crucial role in the education of children.

Educating to give "shape" to the subjects gains prominence in the formation. In modern school, the spaces are carefully delimited, the set time and the learning are organized in stages. So, to be a child for modernity is to constitute a mode of being regulated by the practices that will help produce a self, in which all must be the same, learn in the same way and assume the same form.

With Kohan [4] we understand the importance of not associating children with small and fragile beings, but he points out the need to understand childhood as a phase of ruptures, experiences of formation and transformation. It can be understood as a conducive creation of experiential situations.

In order to do so, it is necessary to create conditions for other modes of childhood and other experiences to be possible. To do so, we will try to demonstrate in this text how childhood is happening in the curricular movements after the implantation process and implementation of Nine Years of Elementary Grade Education. We use as a methodological choice the inspiration in the cartography that, strategically, allows to follow a constructive process always in movement, perceiving it as transient and with multiple possibilities. [5,6]

The research was carried out in the city of Jequié, Bahia State, with a class of 1st grade of elementary education in the Senador João Calmon Educational Center, which has an average of 22 students. Along with the text, we will use John Calmon to refer to the school, for this is how it is commonly recognized by students and teachers. João Calmon is a couty public school located in Mandacaru, a peripheral district of Jequié, with six classes from the initial years of elementary school, which totalizes 298 students and six teachers.

\section{The Rhizomatic-Moving Curriculum with the Help of Difference}

We defend the need to think of the curriculum in its bifurcations, in its escapes and lines of escape. The concepts of the Deleuzian difference thinking are used to think the virtual lines in the curriculum territory. Understanding the virtual as a real power; these lines are creative movements anchored in the difference. For Deleuze [7] "[...] a life contains nothing more than virtual aspects. It is made of virtualities, events, singularities. "Therefore, the virtual is not something that is lacking in reality, but that is capable of being update.

A curriculum, by nature, is difference. it is rhizomatic. But a curriculum is also made up of orderings, sequencing, routines. So what is it, with the help of Deleuze, [8] to think the curriculum for difference? Prioritize difference rather than identity and follow ramifications. [9] To do so, the curriculum of the Nine Years Elementary Education should be read as a rhizome. After all, in it we find a set of scattered lines, all running at the same time, at varying speeds. The rhizome is open, connectable, detachable, composed of different lines, susceptible of receiving modifications constantly. Lines are constitutive elements of things and events, and therefore are constitutive of this curriculum. If the curriculum is an open system, composed of varied lines, it also composes lines. Difference can proliferate in the curriculum by multiplicity.

Multiplicity is one of the principles of rhizome, and can be understood as the opposite of unity. Thus, they are multiple, abundant and rhizomatic. It has no subject and no object, but dimensions that grow changing nature. "The multiplicities are defined by the outside: by the abstract line, line of escape or deterritorialization according to which they change their nature in connecting to the others." [6] So you have to think of a curriculum that is rhizomatic and moving at the same time. It is in wide openness and fluid movement for the compositions.

So, it is worth questioning, what's a resume? We bring as a question to this experimentation lines of curriculum outlined in this research, whose objective is to follow up the childhood in the curricular movements in a class of the first year or level of the Elementary School of the John Calmon school, that, fulfilling Law 11.274, of February, 2006, Implemented and is implementing the Nine Years Elementary Grade School Education. The said school included the six-year-old and is reorganizing the school curriculum. Accompanying a curriculum by mapping it is to build an open map of territorializations, prescriptions and segmentarity, and re-territorializations, whereby it flees and elopes.

For this, we fail to understand childhood as a stage associated with children as small and fragile beings to understand it as a phase rich in ruptures, powers and experiences of (trans) formation, [12] which translates into the potentialization that is given to what children think, feel and think, in order to think this rhizomatic-moving curriculum.

What are the thought images echoed in John Calmon's school about what a curriculum is and what childhood is? We perceive the existence of disciplines, knowledge, teachers, children, textbooks, contents, children's literature, exercises, activities, knowledge, tables, students desks queued or in circles, conversations, explanations, projects, teaching.

This is the curriculum already thought, but the main highlight is what we look at in the curriculum. It is necessary to change the focus, because there is a leak, an exit, a rhizome. The big challenge is to record the curriculum lines that make multiplicity work. For this, we must think of multiplicities.

Through the virtual, several curricular movements are engendered, affecting each other, because to operate with multiplicity is to operate with difference, with becoming. I am talking about a curriculum seen rhizomatically in the middle, which never closes and is permanently open to change. We emphasize that such a curriculum is difficult to be described and apprehended.

To do so, we draw lines of possibilities for a curriculum through the curricular experiences experienced with the practicing subjects of John Calmon, the children, movements that escape the larger curriculum. 


\section{Tracks to Compose Childhood in the Curriculum: A Brassy Zigzag}

In order to compose / recompose childhood in the rhizomatic-moving curriculum, we have adopted some clues: through the observations and conversations that took place in the classroom and in the school spaces during the months of the research, many curricular inventions were happening with good meetings with children. It is the constitution of Track 1 - Desiring lines that boost childhood in school. Through the plays shared in the playground it was possible to understand the importance of these in children's compositions: Clue 2 Playing, the pulsating movement in / from childhood. Through story-making workshops, many inventions have been woven, together with them the desire for a more vivid and colorful curriculum; this is Clue 3-The Children's Invention in story-making workshops. These clues led us to compose movements from the assemblies created with them and to suggest a map of childhood in the curriculum of the Nine Years Elementary Grade School in John Calmon.

\subsection{Desiring Lines That Boost Children in School}

How to talk about curriculum, school, research, childhood, education, but from / with / for children? What are the desirable lines of children on the curriculum? What matters is narrating facts to talk about them with the theoretical contributions, especially from Deleuze, to understand a little of what is happening in school.

We try to know, "What is a curriculum?". In general, we look for the common aspect under the difference, trying to find in the curriculum its unit. To think the curriculum with the Deleuzian difference is to take the focus of the identity thought and to seek the criterion of the difference by the event. So the difference is what comes in the middle, in the space-between. This is what is still in the process of being formed, of curricula in reality power to be formed. It is an invitation to listen to the children, their contributions and their desires for a more interesting, more colorful curriculum.

To do so, we will use the observations and the conversations with the children during the classes and in other spaces of the school, to potentiate and compose the map of this curriculum. We emphasize the importance of bringing throughout the text the records of the field diary in order to map and problematize the data.

When the school is open to the world, the molar dimension "stutters", the plan of immanence of life opens, life floods the territories, causing them to transform and with what other ways to constitute school and curriculum are thought. We realize that children refer to the field of possibilities of another school, another curriculum. In this process, not everything in the territory is plaster; the fissure happens when there is a positioning that allows to think other ways of arriving at a place, to constitute a certain knowledge, to learn the amplitude that there is in the world.

Using the devices, observations and conversations with children as clues to think about childhood and the rhizomatic-moving curriculum allowed us to problematize the plastering of the curriculum and the mechanisms, escape lines, to overcome the binary hard segments and, thus, produce singularization processes. The children denounce the importance of the school being open to life and of teachers being attentive to the details that are currently being expressed in classroom, either through a speech, an opinion, a complaint, a violence or silence.

They demonstrate that the school space and the elementary school activities have changed the constitution of childhood, and they perceive this rupture through schooling and the distance that begins to be established between imagination, creativity and school. Learning gains prominence in this composition. We can know how the children of the first year begin to present their first impressions about the elementary school.

\subsection{Play: The Pulsating Movement in / of Childhood}

Joao Calmon's recreation interval or break is movement and mixture. Movement, because we perceive that it is a space of creation and inventiveness. The driving space is composed of the classrooms corridor, the background and the front area of the school. What do they play with? With the body. It is a mixture of sensations, actions and creations among children. Here the children of the first year or level are invited to dialogue with their peers.

The children went on just constituting groups. In each group I perceived an intentionality, a different proposal to compose in the break. It is interesting to note that the children of the 1st level did not form homogeneous groups, but they were with other students of the 2nd and 3rd levels. I realize that worrying about bringing six-year-olds closer to seven- and eight-year-olds is not a problem for them. Spontaneously, six-year-olds make up the groups diversely and are attentive to the movements of others.

Deconstructing some pre-established perceptions, look at the child's world, and rethink the play. While they play, they produce other plays. Power of creation. What kind of joke is being invented every day? We argree with Corazza [2] that children are inventing new ways of being in their relationships with themselves and with adults. By the jokes they potentiate and (re) invent (new) proposals to build the curriculum, for example. So what are we going to do, what the adults will do, except to face the urge to rebuild a new dawn for school?

We argue that by creating the rules for a game, children exercise creativity, imagination, group negotiations. There is power in the child. We need to observe / contemplate the games. Sharpen sensitivity. The moment of play in school should not be the moment when teachers go to the cafeteria to have coffee, talk, but a space to observe / contemplate children, be open to feel what it conveys without speaking verbally. The body speaks, expresses, demonstrates.

It is necessary to spare time to play, which is not reduced to half an hour. Rethink the delimitation in the routines. Is there time to think and create? It is still necessary to find the backyard from home in school. Space of inventiveness and potency of life, in which children, through various possibilities of creation, imagine situations of free and spontaneous form. We are talking 
about the establishment of good meetings, with activities that move thinking and creation. And such activities can not be restricted only to recreation interval.

It is necessary to rethink the space and time of playing in elementary school. Children create their play, especially in the playground. In what ways can routines be designed so that the play does not have a fragmented time? Ended up! Now it's classroom!

Therefore, spaces in the school need to be better used. The classroom should be a space of creativity and inventiveness. The school structure should make it possible to think about these issues. Where is the ludic space? An open space for invention. A pre-prepared place for the child to experience boundlessness.

The recreation interval and its compositions. In relationships, plays, whether they spark joyful meetings or sad encounters, constitute themselves as activities, as intercessors for learning. In this relationship, in addition to meetings among children, meetings of teachers and other school officials with children should be held. Thus, networks of conversation are established and shared: love expressed in the acceptance of the joking invitations, the smiles that resonate in children's experiences, the exchanges of knowledge that are established in the conversations, and the information and examples that are transmitted.

John Calmon's curriculum is being moved with and from the playful intercessors. The movements that awaken and the emotions provoked are triggers for reflections and problematizations. In this sense, we are mapping this curriculum that insists on escaping, and denounces that nothing is finished, that its strength lies in the possibility of moving with the construction and involvement of children in this process.

\subsection{The Children's Invention in the Making-Story Workshop}

The idea of storymaking workshops came about because of the children's interest in storytelling issues. In the moment of the wheels, listening to stories, children create and invent. We perceive the potentiality of those moments and we decided to expand through their proposals from the idea presented and create fables with characters. When invited to create stories, the children present lines to think the curriculum and everything beautiful in the meetings.

Most of the time, workshops took place in John Calmon's first-year or level classroom or in the resource room. Once a month we had a workshop, and according to the teacher's availability to spare and provide her class time for our meeting, usually lasted from one hour to one and a half hours. When they were held in the resource room, it happened in groups of seven to eight children, but if it was in the classroom, the whole group participated, helping in the approach with the children and powers of conversations.

In the workshops, many stories were created, but we present in this text two moments which were potentials of the conversations with the children of João Calmon, they are so denominated: 1) "From the happy teddy bear to Frederico Godofredo": in this workshop, we started with the magic of stories Creation from the puppet, and the group made an invitation to know in literature a boy named Frederico Godofredo, who taught a lot about the importance of being a happy and motivated child; 2) "The Lions of My School", an inventive space that fostered a moment of questioning by the children about how the curriculum is happening in João Calmon, pointing out lines to problematize childhood from this proposal.

It was then possible to use story-telling to potentiate encounters, and in these encounters with children, many conversations took place, and these conversations moved the way of thinking to reflect on situations and subjects that occurred in the classroom, in the curriculum, giving clues to map / record the orientations, directions, and creations made by the children of how childhood was going on in John Calmon's curriculum. We understand that in addition to the prescription of the Nine-Year Elementary Grade School children, they live intensely the curriculum in John Calmon.

Childhood is an immanent life implied by infinite, communicating movements which bend one another. Therefore, to think the life-childhood with these children of John Calmon's, is to map it, to slow it down, without, however, limiting it. In the rhizomatic-moving curriculum, what we have are these singularities produced in the formative circuits of childhood. It is not fixed in norms of behavior, in organization guidelines, but in the movement that is made is that it is being created.

\section{Conclusions}

As already emphasized here in this text, to record a difference curriculum that is rhizomatic and moving is to track lines and traces of a curriculum at their bifurcations. It is to feel, to speak and to see its power, its movements of creation. It is to follow the traces of the event, the good meetings (those that increase our power to act). It is to see a curriculum in the middle, understanding that it never closes, but that it is permanently open. Such a curriculum is difficult to grasp, but it is necessary to trace curricular experiences that fork, cause metamorphosis, and escape from the larger curriculum.

It is worth emphasizing that only a plan of immanence can make the curriculum open to the difference. The plane of immanence is not a concept, but the image of thought, the image of what it means to think, that is, the use made of thought. Unlike a method, from the knowledge about the brain, to understand the image of thought we need to separate the brain issues, such as memory and reflection, to retain what thought can rightfully claim, that is, what can be brought to infinity. This is the constitution of the image of thought: the movement of the infinite. We can emphasize that the plan does not, of course, consist of a program, a project; It constitutes "[...] the absolute ground of philosophy, its Earth or its deterritorialization, its foundation, upon which it creates its concepts." [13]

We emphasize the importance of the place of creation not being based on transcendence, however,it must be involved in immanence. Thus, the concept is not outside of immanence, but belongs to it; Once created the concept in the plane of immanence, they do not separate. [13]

We have discussed throughout the text that thinking life in multiplicity is thinking of a world without transcendence, 
without the idea of eminence. A transcendent field belongs neither to an object nor to a subject. The way in which Deleuze and Guattari [13] have created various concepts, change our way of looking at the world, of experiencing the world, of making a cut in the world to understand it, of problematizing the school.

The plane of immanence is not intended for description or for representation. The concepts that compose it do not point to a way of seeing the world, but they call attention to what is important to see in the world. That is, we do not want to say "that's the way it is", but to provoke questions, such as "what if it were so?" Moreover, when we think of the concept of curriculum, we do not intend to ask, "what curriculum type does it belong to?", "What it is." We aim, however, to problematize: "what can it do?". What matters now is to know the compositions made and if they are powers of action.

We need to exercise detachment. Open the path; that is our function. For this, it is important to think about the sensations in the curriculum. What makes one scream? What causes good meetings? [14] Through the accompaniment of movements, meetings and disagreements, the lines were drawn and we look at childhood in the curriculum with the help of difference, because it is rhizome, it is open and accepts different strokes and makes one think different things. It is open, and so it does not look for definitions for what it is. To take the path of an escape line that is always the fuse of creation. "It is a stampede that things progress and signs proliferate." [6]

We emphasize that, like Professor Deleuze, [15] we are not concerned about teaching, because this verb is committed to representation and resemblance, and can not be part of a curriculum of difference. Learning is related to the desire of each, with the signs. "Learning to swim ... means to compose the singular points of your own body ... with those of another figure, another element that dismembers us, which leads us to penetrate a world of hitherto unknown problems, unprecedented. " [16]

How to be in the classroom as a teacher and not "fall" in the transmission and identity? How can the curriculum immanence plane be extended? No answer until then. But do we have any clues? Yes, we have some suggested by the children. Life-childhood and the rhizomatic-moving curriculum, with the help of difference, should enable brisk and powerful encounters. The images produced with / by the children can contribute to the problematization of the stereotypes about childhood in the curriculum of Elementary School.

In this discussion, we emphasize that childhood thought as experience, breaks with the pedagogical and philosophical discourses that have in childhood a "container" to accommodate with the interests of adults. But, we are like Kohan [4] bringing a conception that speaks of the child experience and potentiates it. Therefore, education based on the experience of childhood does not prepare it for the future.

As we have already pointed out, what we are trying to do with such a discussion is to displace the sense of childhood and child based on chronology, logic and development, widespread classifications in our schools and to think of a childhood in movement, which does not settle but escapes, since the child is multiplicity and intensity.
The practicing subjects in school, mainly the children, continue to create with the curriculum in the school and, for that, it is necessary to follow other paths that are not regulated in the documents nor in texts that circulate by the school. In the proposal of the Nine Years Elementary Grade School Education these wanderings are not described.

Along with the documents, there are intensities in the movements; there is the possibility of encounters that can not be paralyzed by the plastered practices, by the crystallizing routines, by the timed time, since the children slide between; they walk by pulsing the what is new. Therefore, there are no impairments to the startup of an escape line and creation of shortcuts in the journey.

It is worth mentioning that public policies come in the attempt to set standards, point out ways, solve problems. The Nine Years Elementary Grade School Education came as a norm that the counties had to adapt. It caused tension, discussion and doubts to the professionals who are in João Calmon. However, they sought alternatives to live with these changes, and possibly are still trying to adjust the school. They show desire and dedication in the accomplishment of the work even before the restlessness that arises.

The Elementary School space is undergoing changes. The entry of the six year old child proposes a dialogue between Early Childhood Education and Elementary School, between ludic and schooling, between learning and desire. It is necessary to rethink the space and time of playing in elementary school. Children create their plays, especially in the playground.

Children and their playful inventions show us that it is necessary to break the senses and pedagogical practices that need to be reinvented, and force us to look for other focuses. Children's rhythms and drives point to the importance of promoting different practices of freedom.

\section{References}

[1] Jequié, Bahia, Departamento Pedagógico. Diretrizes curriculares do Ensino Fundamental do município de Jequié, Secretaria Municipal de Educação e Cultura, Jequié, 2008.

[2] Corazza, S. M, Noologia do currículo: vagamundo, o problemático, e assentado, o resolvido. Educação \& Realidade, (27). 131-142. jul./dez. 2002

[3] Kohan, W. O, Infância. Entre Educação e Filosofia, Autêntica, Belo Horizonte, 2005

[4] Kohan, W. O, Não há verdade sem alteridade. A propósito de "Devir-criança da filosofia: infância da educação", in Kohan, W. O. [org], Devir-criança da filosofia: infância da educação, Autêntica, Belo Horizonte, 2010, 7-13.

[5] Passos, E., Kastrup, V. e Escóssia, L. da [orgs], Pistas do método da cartografia: pesquisa-intervenção e produção de subjetividade, Sulinas, Porto Alegre, 2014

[6] Deleuze, G. e Guattari, F, Mil platôs: capitalismo e esquizofrenia. Ed. 34, Rio de Janeiro, 1995.

[7] Deleuze, G, A imanência: uma vida, Educação \& Realidade, 27. 10-18. jul./dez. 2002.

[8] Deleuze, G, Diferença e repetição, Graal, Rio de Janeiro, 1988.

[9] Deleuze, G, Conversações, Ed. 34, Rio de Janeiro, 1992.

[10] Paraíso, M. A, Diferença no currículo, Cadernos de Pesquisa, 40 (140). 587-604. maio/ago. 2010.

[11] Brasil, Senado Federal, Lei 11.274, 06 de fevereiro de 2006. Estabelece as diretrizes e bases da educação nacional, dispondo sobre a duração de 9 (nove) anos para o ensino fundamental, com matrícula obrigatória a partir dos 6 (seis) anos de idade. Diário Oficial [da] República Federativa do Brasil, 2006. 
[12] Kohan, W. O, "A infância da educação: o conceito devir-criança”, in Kohan, W. O. [org], Lugares da infância: filosofia, DP\&A, Rio de Janeiro, 2004.

[13] Deleuze, G. e Guattari, F, O que é a filosofia? [3a ed], Ed. 34, São Paulo, 2010.
[14] Spinoza, B. de, Ética, Autêntica, Belo Horizonte, 2008.

[15] Deleuze, G, Proust e os signos, [2a ed], Forense Universitária, Rio de Janeiro, 2010.

[16] Deleuze, G. e Parnet, C, Diálogos, Escuta, São Paulo, 1998. 